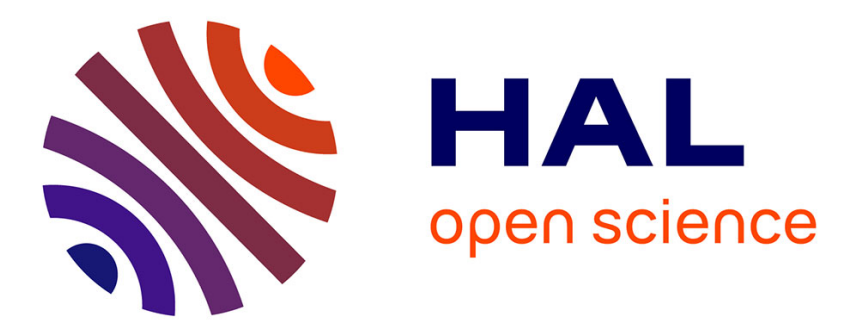

\title{
The Diplomatic Lead in the United Nations Security Council and Local Actors' Violence: The Changing Terms of a Social Position
}

David Ambrosetti

\section{- To cite this version:}

David Ambrosetti. The Diplomatic Lead in the United Nations Security Council and Local Actors' Violence: The Changing Terms of a Social Position. African Security, 2012, 5 (2), pp.63-87. 10.1080/19392206.2012.682471 . halshs-00707155

\section{HAL Id: halshs-00707155 \\ https://shs.hal.science/halshs-00707155}

Submitted on 20 Sep 2019

HAL is a multi-disciplinary open access archive for the deposit and dissemination of scientific research documents, whether they are published or not. The documents may come from teaching and research institutions in France or abroad, or from public or private research centers.

$$
\text { Copyright }
$$

L'archive ouverte pluridisciplinaire HAL, est destinée au dépôt et à la diffusion de documents scientifiques de niveau recherche, publiés ou non, émanant des établissements d'enseignement et de recherche français ou étrangers, des laboratoires publics ou privés. 


\title{
THE DIPLOMATIC LEAD IN THE UN SECURITY COUNCIL AND LOCAL ACTORS' VIOLENCE: THE CHANGING TERMS OF A SOCIAL POSITION
}

\author{
David Ambrosetti
}

\begin{abstract}
Inspired by interactionist and constructivist sociology, this paper focuses on the UN Security Council (UNSC) as an arena with its own social rules and bureaucratic routines. It presents the informal position that UNSC diplomats delegate to specific members of the UNSC, the position of "leader," when dealing with specific dossiers. Indeed, a change occurred during the 1990s and the early 2000s in how UNSC diplomats considered the task of leading a UN peace operation, notably in regards to the use of offensive military. The analysis of this change is documented with empirical material concerning the French leading position in the African Great Lakes region, from Rwanda in 1993 to DRC in 2003. A second instance of diplomatic leadership considered is the leading role assumed by the British authorities in Sierra Leone (1991-2002). The new "leadership" role calls upon UN diplomatic leaders to better protect the credibility of "their" peace operations. It sheds a light on the importance of deterring or incentive messages embedded in routine UNSC decisions, and how routine practices may change when facing critical situations.
\end{abstract}




\section{INTRODUCTION}

The crisis in Côte d'Ivoire after the November 2010 elections held under the auspices of the UN brought some commentators to point out the leading role played by France in the UN Security Council (UNSC) and Opération Licorne on the ground, whether with suspicion or appreciation. ${ }^{\mathrm{i}}$ When it appeared that former president Laurent Gbagbo was contesting the elections, the UNSC and the international forces there (blue helmets and French troops) opted for a firm military response. This event can be analyzed from various standpoints. In this paper, we examined a change that has occurred during the 1990s and the beginning of the 2000s on how the UNSC diplomats have considered the task of leading a UN peace operation and on the use of offensive military means to support peace operations. In terms of France assuming a leading position in a French-speaking African country, the UN mission deployed in Côte-d'Ivoire was not novel. ${ }^{\text {ii }}$ Yet, this practice was not business as usual in 2010. The French learned from their experience in the African Great Lakes region, from 1990 to 2000. Between the DRC and Côte-d'Ivoire, the notion of the diplomatic leading position in the UNSC changed.

France was the UNSC member with the strongest bilateral involvement in the Rwandan armed conflict between 1990-1994, which included the rapid deployment of troops (opération 'Noroît') and military trainers (Détachement d'assistance militaire et d'instruction 'Panda'). As armed confrontation and ethnic-oriented political violence escalated in Rwanda, the UN launched a peace operation (mission des Nations Unies au Rwanda, MINUAR) in 1993. France was the informal leader of the UNSC in Rwanda. Such external involvement could not prevent the internal military and political dynamics from falling into three months of genocide against the Tutsi in Rwanda, preceded by a "politicide" against Hutu politicians, 
journalists and activists rejecting the radical ethno-nationalist anti-Tutsi Hutu Power ideology. The genocide claimed some 800,000 lives. This experience eventually affected the position the French delegation held within the UNSC concerning armed conflict management in French-speaking Africa. Despite the subsequent armed conflicts that devastated the African Great Lakes region (Zaire/Democratic Republic of Congo, and Burundi), French military and diplomacy went through a nine-year retreat after Opération Turquoise had deployed in the summer of 1994 in Rwanda and Eastern Zaire. This retreat came to an end with a cautious diplomatic return to the DRC in $2001 / 2002$, followed by a new military operation, the Frenchled European Union operation, Artémis, in the spring of 2003.

The French diplomatic leading position vis á vis French-speaking Africa, first assumed, then lost, then recovered, provides us with a view of the everyday work of UNSC members; and with an analytical prism for interpreting the evolution of UN peacekeeping operations. ${ }^{\text {iii }}$ The interest of the issue for African security is unquestionable. Whether in 1994 or 2012, the UN has been a central actor in conflict resolution in Africa. Since the beginning of the 2000s, it has reached an unprecedented level of activity in peacekeeping operations, ${ }^{\text {iv }}$ particularly in Africa: in 2009, an average of sixty percent of UN Security Council's deliberations addressed African issues and seventy percent of the UN blued helmets were deployed in Africa. ${ }^{v}$

UN peace operations have long been under scrutiny by social scientists and international relations scholars (IR). ${ }^{\mathrm{vi}}$ These studies frequently question the curtailed and challenging implementation of the UNSC resolutions in the field; they look for answers in UN organizational features, ${ }^{\text {vii }}$ or in local actors' political and military strategies. ${ }^{\text {viii }}$ We adopt a different perspective inspired by interactionist sociology. In this approach, the focus shifts to the UNSC as a situated arena of repeated interaction between fifteen diplomatic delegations 
(and UN secretariat's officers and other guests invited to speak at the UNSC table). We track specific positions held by UN diplomats in this arena of interaction. This approach allows us to trace the informal, bureaucratic position of actors in specific cases as a collectively acknowledged and sanctioned position attached to specific social rules and collective expectations among UNSC diplomats. The result is a new intersubjective norm.

The role of leader in the UNSC has witnessed two changes. The first is how UNSC diplomats have conceived of the relations they should keep with local belligerents who carry out violence. The second is the conditions under which UNSC diplomats should themselves resort to military solutions or actions. We use the term of normative change in this regard, pointing to different collective expectations of what is appropriate, what should be done

We look at the changing French diplomatic leading role concerning the Rwandan conflict, and the consequences of this case for international conflict management on the conflict in Zaire/DRC begun in 1996. A second case of peacekeeping, the Sierra Leonean conflict from 1991 to 2002 under British leadership, confirms the change in the leadership norm in the UNSC for international peacekeeping. The potential political significance of the informal position of the UNSC diplomatic leader was first revealed during observations by the author's stay within the UNSC alongside the French delegation in 2002.

The paper has six sections. First, we address the theoretical and methodological implications of this research for constructivist IR theory. Second, we outline what we mean by the "leadership" role and how it has traditionally been framed at the UNSC. We then explore three different situations that affect diplomatic leadership at the UNSC and their relation with local belligerents and violence. The first situation occurs when protective bilateral relationships exist between a UNSC member state and a country in turmoil prior to a UNSC involvement. We look then at how these relationships evolve when brought into the 
UNSC diplomatic arena. Fourth, we look at a second situation, when peace operations are under way. We highlight the deterring or incentive nature of the messages that the UNSC sends to the local belligerents through its routine decision-making. Fifth, we look at the third case where UN peacekeeping operations face critical situation on the ground with high international media coverage. Finally, we claim that such critical moments in Rwanda in 1994 and in Sierra Leone in 2000 have reflected a normative change concerning the way UNSC members have conceived of and assessed the leadership role in UN peacekeeping operations since the early 2000 s.

As mentioned above, these three situations and the normative change presented in the paper result from the analysis of two instances of diplomatic leadership and their effects on local actors. First, the Rwandan conflict (1990-1994); and second, the Sierra Leonean conflict (1991-2002). DRC (ex Zaire) is only of interest as a follow-up to the multilateral diplomatic process that started in 1993 for the Rwandan conflict.

\section{DIPLOMATIC PRACTICES AND ROLES: AN INTERACTIONIST}

\section{SOCIOLOGICAL APPROACH}

This research has two theoretical and methodological implications. The first is to focus on the UNSC as a particular arena of interaction, with its own social rules, norms and routines, enacted and reproduced by inter-individual everyday interactions. The second concerns the empirical importance of one informal leading position that UNSC diplomats collectively delegate to the leading actor when dealing with specific dossiers. When this position exists which is not necessarily always the case (according to different degrees of "delegation") - it is a rather technical, bureaucratic role that is poorly institutionalized. This informality can cast doubt on its political significance. In the sequences studied below, however, the role of the 
leadership position provides us with insights into diplomatic dynamics inherent in the UNSC's work.

What can be learned from the study of situated political interactions within the UN Security Council? Can we find more than a succession of tactical moves from rational, goaloriented diplomats serving member states' foreign policies? The answer lies in what IR theory terms as constructivist ontology: interactions within the UNSC take part in the social construction of international political reality. They reproduce and (re-)mould social institutions, rules and norms. The norms represent shared ideas and mental categories, ${ }^{\text {ix }}$ whereby actors define their practices towards others, define their interests, and even define the identities and roles they acknowledge of one another. ${ }^{\mathrm{x}}$ Constructivist and critical approaches have challenged the neorealist mainstream on international politics and security studies. ${ }^{\mathrm{xi}}$ They have inspired a great number of studies dealing with international security, interventions and peacekeeping operations. Two main trends, however, within this literature do not correspond to what I intend to do with the present research.

First, constructivism and critical IR theory have often been mobilized in large debates about current liberal interventionism as a whole. Some applaud the apparently unstoppable diffusion of ideas of humanity and human solidarity among international politics practitioners worldwide, ${ }^{\text {xii }}$ as well as and the victory of Western supposed liberal political preferences. ${ }^{\text {xiii }}$ Others have warned against processes aimed at "securitizing" control over "human surplus" to the benefit of the global capitalist system, ${ }^{\text {xiv }}$ or against the edification of a quasi-imperial international system that deprives intervening states any political strategy to the benefit of international bureaucracies and transnational NGOs. ${ }^{\mathrm{xv}}$ Such broad debates exceed the scope of the present study. 
The second difference is methodological. Although grounded in the same ontological assumptions as interactionist sociology, IR constructivist accounts of international intervention and peacekeeping often turn into macro-sociological analyses or macro-histories of ideas, rather than an examination of concrete interactions between clearly identified individuals. ${ }^{\mathrm{xvi}}$ They apply the mechanisms unveiled by interactionist sociologists (from the Chicago school notably) to the states as if they are "individual" actors, similar to the unitary state actor assumption that informs much of realist IR theory. ${ }^{\text {xvii }}$ The reified state is socialized, while seeking prestige or at least peer acknowledgement. This is supposed to explain how states happen to share similar norms, how they construct their own identities, ${ }^{\mathrm{xviii}}$ and how they strengthen or weaken their own self-esteem and "ontological security". xix

Rather than the anthropomorphized state, we prioritize inter-individual interactions and their effects. ${ }^{\mathrm{xx}} \mathrm{We}$ argue that processes of identity and role formation, norms diffusion, etc. do not necessarily occur within a state at once, but rather occur within specific groups, and spread across states through inter-individual interactions. In this sense, international politics is also constituted by arenas of situated interaction. Inter-individual interactions need to be examined through in-depth direct observation to ascertain regularities or changes in the reality they co-constitute on a day-to-day basis. ${ }^{\text {xxi }}$ In what follows, we intend to circumscribe the fractions of international political reality that are specifically constructed within the UNSC among the diplomatic delegations in the course of their everyday interactions. This does not mean that the UNSC is an island, isolated from larger international political dynamics. We do claim, however, that the interactions of UNSC members must be understood on their own merits. ${ }^{\text {xii }}$

As a result, the present study supports the recent "practical turn" in the social sciences, ${ }^{\text {xxiii }}$ and notably in IR and security studies. ${ }^{x x i v}$ Admittedly, massive ethnographic 
observations on its members' practices do not apply very well to the UNSC, due to the existing barriers that limit access to them. But when the opportunity to overcome these barriers and to observe the day-to-day UNSC work arises, some specific "logics of practice" become evident. The leader, as an informal but precise social position within the UNSC, opens a window into how the interaction among individuals is a specific context shapes norms.

\section{THE UNSC DIPLOMATIC LEADER IN PEACEKEEPING OPERATIONS}

In the summer of 2002 the author had the opportunity for a ten-week internship period within the UNSC alongside the French delegation; and was in charge of some of the African issues then discussed at the UNSC table (Sierra Leone, DRC, Bissau-Guinea, and Somalia). As this participatory observation period was rather short, the detection of some specific social positions assigned to, or claimed by, UN diplomats, was prioritized. Such roles could then support further theoretical and empirical research.

Individuals hold various identities (belongings to multiple well-defined groups) and social positions (or roles) among these groups. Such identities and roles are necessarily attached to normative prescriptions, that is, to collective expectations that are socially positively sanctioned. Each failure to meet these expectations may generate some doubt within the group concerning the ability of the current holder of the role: it can lead to the loss of this position. ${ }^{\mathrm{xxv}}$ Such processes remain difficult to grasp, though, since social positions (and the collective expectations attached to them) are not systematically formalized (textually, legally, or bureaucratically), nor necessarily formulated with words. They often remain informal, embedded in implicit knowledge, or what Giddens called the "practical consciousness" of the practitioners. ${ }^{\text {xxvi }}$ 
Within the 2002 UNSC, it is the role played by the British concerning the Leonean case that brought the author to investigate this particular role of "leader" in the UNSC. Through this position, one or several delegations are informally granted a driving position in the negotiation and decision-making process concerning a particular issue, and at a particular moment (leaders can change).

The term "lead" is actually directly taken from the indigenous diplomatic lexicon in the UN; it was often discussed among colleagues dealing with the Sierra Leone and the Democratic Republic of Congo dossiers ("on DRC, we [the French delegation] had the lead,"xxvii "the UK had the lead on Sierra Leone,"). More sociological evidence was gathered by observing the daily social division of multilateral labor and the particular roles and tasks assumed by these leading delegations prior to any consultation with Sierra Leone or the DRC. The precise moment when the delegations were speaking during private consultations and public meetings, and the kind of arguments and concerns they broached, were not accidental. There was a pervasive form of influence at stake in the course of the interaction and in the achievement of preliminary tasks that were collectively expected.

Experts who keep a close eye on international conflict resolution and peacekeeping operations often mention this leading position. In some cases, single dossiers of conflicts are at stake. ${ }^{\text {xxviii }}$ Others mention diplomatic leading positions referring to specific thematic issues, cutting across different conflicts and regions, such as Canada's leading position on Human Security in the UN during the late 1990s, or the United Kingdom's on the Kimberley process for controlling "blood" diamonds. Still others stress how the existence of an active diplomatic leading role within a multilateral arena bodes well for the efficiency of the actions to be adopted. ${ }^{x \text { xix }}$ 
Authors working on multilateral negotiations (commercial ones, for instance) show a great familiarity with this position and the entrepreneurial conception it connotes, ${ }^{\mathrm{xxx}}$ notably on the formation of coalitions, ${ }^{\mathrm{xxx}}$ or on the importance of individual leaders in foreign policy. ${ }^{x x i i}$ This obviously differs from an IR perspective on global leadership, such as that about American power, ${ }^{\text {xxxii }}$ or about hegemonic order and the global political economy. ${ }^{\text {xxiv }}$ Leadership in the present case study concerns a diplomatic delegation, that is, a limited number of persons in a delimited arena of regular interaction, about limited issues.

First, the members of the Council often expect a deeper involvement in a dossier of conflict when a leading delegation has previously advocated for it and has overcome reluctances among its peers on the Council to put the new dossier on the agenda (this is a nonwritten rule among UNSC members). They also usually expect leadership from any UNSC member liaised to the state in turmoil (such as a former colonizing power still active in the region, a regional political ally, etc.).

The leadership position presupposes practices such as a special monitoring of the situation, the drafting of resolutions or presidential statements (at the very least), the constant negotiation with UNSC delegations (particularly the main financial contributors to the UN peace operations budget), discussions with the Secretariat services (when discussing operational options and available means or the appointment of UN representatives and senior staff in the field), and working with troop contributing states. No official prerogative stems from this informal position. Yet, the member assuming the leadership position should inspire some confidence among its colleagues when suggesting a line of action. In the consultation room, the leading delegation usually speaks immediately after the President. Equally, it is the first to congratulate its partners when a decision is reached and announced during public sessions. 
This position does not amount by itself to a politically dominant position, which would inspire competition among UNSC members. It is a purely bureaucratic informal role. In many instances, such as when dealing with the most peripheral conflicts (in the Africa of the 1990s), leading positions were finally held by default and under the friendly pressure of permanent members. In other cases, permanent members were involved from the very beginning (France for Rwanda from February 1993 to the start of the genocide on April 6, 1994, and for Côte d'Ivoire in the 2000s); they sometimes share this position with close partners to the UN (such as the U.S. with the U.K. and Norway concerning Southern Sudan in the 2000s). ${ }^{\mathrm{xxx}}$

If a delegation has successfully petitioned the UNSC to act in a country facing a security threat (for its political stability and/or for the stability of the region), the delegation will want to preserve its influence at the UNSC. The leading delegation will likely have already demonstrated familiarity with the dossier, the type of challenges involved, as well as a demonstrated ability to be heard locally, to have some local levers of action, while not alienating the Council from local actors. In turn, the leading delegation will harness new multilateral resources from the UNSC: material (human, military), organizational, legal (mandates), and symbolic ones (international legitimacy). This might help reduce the domestic pressure on this country regarding the financial burden and the politically expensive military operations associated with peacekeeping. But multilateralization should not appear to change strategic preferences or to engender a loss of control of the local political game.

The objective of preserving diplomatic influence in the UN may intersect with the prospect of impacting local events and local political hierarchies. At least three different situations deserve attention, in order to properly appreciate the relation between how a diplomatic delegation is liaised with the political-military forces of the conflict locally (outside the UNSC) and how it will behave as a leader at the table of the Council. Starting 
with the situation in 1990-1994 Rwanda, we first examine the impact of a pre-existing protective relationship, between a UNSC member state, in this case France, and its partner, the Rwandan regime before July 1994.

\section{MOBILIZING THE UNSC IN SITUATIONS OF PRE-EXISTING PROTECTIVE}

\section{RELATIONSHIPS WITH LOCAL REGIMES}

In this section, we scrutinize the process whereby UNSC members ask the Council to address particular topics. As mentioned above, there is often one sole delegation that plays a decisive role in forcing a particular issue onto the UNSC agenda. For this delegation's colleagues, such efforts reveal some interest and some pretension to sway the course of the UNSC future actions toward this situation. This is particularly the case when close relations already exist between the two states, like in privileged "zones d'influence" that are well acknowledged among UNSC members. The cases we study in this paper stress different kinds of relations between such pre-existing zones of influence and UNSC's mobilization of a dossier.

\section{Rwanda 1990-1994}

The notion of a zone of influence describes the UNSC's involvement (March 1993) in the armed conflict in Rwanda between the (Northerner Hutu-led) regime of Juvénal Habyarimana and the (exiled Tutsi-led) rebellion of the Rwandan Patriotic Front (RPF). In 1993, the French delegation asked for a UNSC intervention in a country whose regime's ties with the French Presidency were well known. ${ }^{x x x v i}$ The "patron and client" relationship is often used to describe this kind of relationship, which is aimed at exchanging military and political protection (from the patron) with diplomatic, commercial, and other geopolitical advantages (from the client). France and postcolonial Francophone Africa is a good fit for this concept, although other external powers were also involved. ${ }^{\text {xxxvii }}$ These ties were all the more obvious when President François Mitterrand's advisors for military and African affairs almost 
immediately assented to president Habyarimana's request for help in October 1990; Opération Norô̂t mobilized up to six hundred soldiers and military advisers. ${ }^{\text {xxviii }}$

After more than two years of bilateral military involvement without any durable improvement, the Élysée palace asked its UN delegation to advocate for the Rwanda dossier within the UNSC. A UN peacekeeping operation was an acceptable solution, as long as it could stop the rebellion's progress and foster a political agreement that would not marginalize the Habyarimana regime to the benefit of its enemies. ${ }^{\text {xxxix }}$

\section{Sierra Leone 1991-2002}

A zone of influence by a member of the UNSC does not always translate to an UNSC involvement. Following military assaults against its army by the Revolutionary United Front (RUF) (composed with elements of the National Patriotic Front of Liberia (NPFL), the rebel movement that was led by Charles Taylor against Samuel Doe's regime in Liberia), in April 1991 the Sierra Leon regime of Joseph Momoh alerted the UNSC. The U.S. and the U.K. delegations were then considered the most interested ones, because of their historical, economic and diplomatic ties with, respectively, Liberia and Sierra Leone. They would, however, only deal with the Liberian issue at the UNSC table in 1993, sidelining the Sierra Leonean case for a long time. ${ }^{\mathrm{xl}}$

One element counted in the UNSC ability to remain uninvolved in Sierra Leone. In the wake of Charles Taylor's invasion of Liberia on Christmas Eve 1989, a military force had been deployed; ECOWAS (the Economic Community of the West African states) agreed to launch the ECOMOG military operation, mainly Nigerian forces that were friendly to Doe's regime. This (limited) patronage benefited from a post-Cold War context where regional organizations were encouraged by the U.S. and its close Western partners to respond to threats and to act as "subcontracting" security providers. This did not provoke too much 
trouble among other UNSC members. Within the UNSC, the U.S. and the U.K. convinced ECOWAS to expand its operation, as the Liberian conflict was spilling over into Sierra Leone. They also provided the ECOMOG with (limited) bilaterally material support. ${ }^{\text {xli }}$

ECOMOG, however, found it hard to deal with the RUF and particularly with the political instability and military coups in Freetown (in 1992, then in 1997). Sierra Leone gained stronger coverage and diplomatic visibility because of its deepening instability and violence. This was particularly the case when indiscriminate violence originated from the Nigerian troops themselves. Indeed, ECOMOG engaged in combat in Freetown after the May 1997 coup that was fomented by mutineers from the Sierra Leone army who had allied with the RUF. The U.S. and U.K. delegations in the UNSC were progressively brought in to more firmly handle the dossier and get more involved in the day-to-day mediation process. 


\section{DAY-TO-DAY MESSAGES TO THE LOCAL ARMED GROUPS AS UN OPERATIONS ARE UNDER WAY}

Local military-political leaders keep a close eye on international interventions and their outcomes, be they directly concerned by the intervention (and linked in one way or another to the international interveners), or totally external to it. In the latter case, they were eager to vet what is internationally acceptable and possible. Diplomatic and military leaders cannot ignore the importance of the messages they collectively send to these armed groups through their interventionist practices. ${ }^{x l i i}$ Yet, in their everyday work, with its own routine and selective urgencies, they do not always spend the same energy deciphering what precise messages they are sending, to whom, and with what consequences.

UNSC Indifference and Genocidal Politics in Rwanda: The Handcuffed French

\section{"Leader"}

The profound indifference reigning in the UNSC regarding Rwanda encouraged the French ambassador to the UN, Jean-Bernard Mérimée, to bring the French presidency's views of the conflict to the UNSC table. ${ }^{\text {xliii }}$ President Habyarimana was perceived as trustworthy by the international aid community. ${ }^{x l i v}$ And the French delegation was the most influential delegation within the UNSC on Francophone African matters. ${ }^{x l v}$ But this influential position also resulted from the support and levers France got from African actors. In 1993, the French delegation was cautious in gaining the support of the states of the region: Rwanda and Uganda (despite president Museveni's links with the Rwandan rebellion) were officially asking for a UN peace operation. The main inhibitor to the French delegation was the concern of the U.S. Congress for runaway UN peacekeeping budgets. ${ }^{\text {xlvi }}$ France used its military support for the U.S. led UNITAF and UNOSOM II operations in Somalia in 1992-93 to gain support. Apart from the U.S. concern, the French demand provoked no collective surprise or negative reactions. 
The UNSC, as a whole, tended to interpret the escalation of political violence exclusively in terms of power-sharing arrangements among belligerents. French-led efforts to exert pressure on the Rwandan "parti unique" (the Mouvement révolutionnaire national pour le développement, MRND) for a multiparty system (1992) and for peace negotiations with the RPF in Arusha (Tanzania) were, therefore, normal practices. Even in the evolving zero sum situation where violence and mass murders from Hutu-Power extremists against Tutsi civilians was evident, France promoted power sharing. ${ }^{\text {xlvii }}$

The UNSC continued to defend the Arusha agreement (August 4, 1993), hoping that the current marginalization of the Habyarimana clan would hasten an internal, peaceful political transition. It thus underplayed the increasing violations of the agreement, the worrying signals about the preparation for mass murders, and the climate of general political violence against civilians. ${ }^{x}{ }^{\text {lvii }}$ Rwanda was even elected as a new member of the UNSC in January 1994 , to encourage it to carry on with the transition. This could not happen without electoral support from the Francophone states among the group of the African states in the General Assembly. It also required the preliminary support of the UNSC members.

The message the UNSC sent was a sort of "the situation can go on this way; it does not really worry us so far." It, however, indifferently applied to the moderate politicians as well as to the extremist forces in the MRND and the Coalition pour la défense de la République extremist party $(\mathrm{CDR})$ that were working at spoiling the transition and were prepared for mass slaughter. The UNSC had sent poor deterrent messages to the Rwandan, Hutu-led political parties and their own extremist forces. 


\section{UNSC Irresolution in Sierra Leone}

Unlike the French authorities in Rwanda, the U.S. and the U.K. kept a prudent distance from the Liberian and the Sierra Leonean dossiers; partly because there were no firm patron-client relationships between these governments. As well, immediate action from outside Africa was not needed because of ECOMOG. The modest multilateral (UNSC) management of the Liberian and Sierra Leonean dossiers, nonetheless, supposed increasing relations with local actors. Apparently, although collectively acknowledged as the most influential delegations locally, the U.S. and U.K. delegations could not afford - or they had no interest - to liaise deeper with local actors in such a post-Cold War (and post-Mogadishu) African context. In accordance with the International Monetary Fund, ${ }^{\text {xlix }}$ they prioritized general elections in both countries before any deeper UN involvement. In the 1997 elections in Liberia, U.S.-backed Ellen Johnson-Sirleaf lost. In Sierra Leone, Western- and Nigeria-backed Ahmed Tejan Kabbah (a former UNDP officer supporter of the SLPP party) won the 1996 presidential election, partly thanks to the international pressure on the former junta, notwithstanding the existing defiance between Kabbah and the Sierra Leonean military leadership. ${ }^{1}$

Constant hesitations, however, affected the UNSC action. The instability among the army boded ill for a resolute UN deployment, as the governmental partner facing the RUF rebels could implode at any moment. As well, any UN action would have to placate the ECOWAS and the Nigerian-led force deployed since 1990 in the Mano River region. Subsequently, painful military reactions were assumed by the ECOMOG, first after the May 1997 coup, then after the RUF launched a new offensive towards Freetown in December 1998 - January 1999. According to Paul Richards, in order not to be political marginalized, while hiding in the forests at the end of December 1993, the RUF increased atrocities in the wake of 
military defeats. It amplified this strategy as international actors were advocating for general elections in 1996 (leading to the infamous campaigns of amputations). ${ }^{\mathrm{li}}$

The RUF thus won a seat at the table of negotiations for a peace deal under the UN auspices. The Lomé Agreement (July 7, 1999) intended to turn the RUF into a respected ruling partner in an extended interim government. One would be mistaken to think that the U.S. and the U.K. delegations did not fully assess this message and its possible perverse effects. But the Lomé agreement resulted from two constraints: first, the difficulty ECOMOG had managing the situation militarily, while open to the scrutiny of the UNSC and its concerns for the loss of civilian lives; and second, the absence of an offensive instrument for the UN secretariat, preventing it from launching a more robust operation in the middle run alongside the chosen local partner, President Kabbah. Once the peace deal was signed, nevertheless, the U.K. delegation took a more resolute lead on the UN mission (UNAMSIL). It carefully sidelined the ECOWAS-Nigerian leadership and worked at isolating and marginalizing the RUF combatants in UNAMSIL. This resulted in the May 2000 crisis.

As we will now see, the 1990 failures in UN peacekeeping operations made the UNSC members progressively acquiesce to a modified model of diplomatic leadership in UN peace operations at the beginning of the 2000s. This model praised the capacity of the leading delegation to rescue diplomatically and even militarily "its" UN peace operation, when visibly threatened, in order to protect UN credibility.

\section{“LEADERSHIP" IN CRITICAL SITUATIONS: DIPLOMATIC FAILURE IN RWANDA AND SUCCESS IN SIERRA LEONE}

When a UN peacekeeping operation faces a situation collectively judged as "critical", one needs to envisage simultaneously the kind of relationships previously established between specific UNSC delegations and local actors, the forms of the UN involvement in the lead-up 
to the crisis, and the role assumed by these UNSC delegations. The practical lessons regarding the crisis' outcomes for them and for the UN as a whole also deserve attention.

In Rwanda, the armed conflict never was a critical concern for UNSC members. The French Presidency and the military assumed what they routinely deemed a stabilizing role (regime protection and military training provided to new recruited "soldiers," among them some future militiamen and génocidaires), and a mediation role in the short run. Along with a climate of indifference and self-censorship by the UNSC, this prevented the French from impeding the genocide.

The French diplomats within the UNSC made two decisive mistakes concerning Rwanda. On the one hand, because of the previous involvement of some French military officers on the ground alongside the Rwandan army loyal to Habyarimana, French diplomats in New York felt the political sensitivity of Rwanda in Paris and thus did not act proactively to block the path to genocide. On the other hand, they depended too much on a hypothetical fall-back position, which was a rapid reaction from the UNSC members in case this "French" dossier went severely wrong. As we know, despite a hundred-day genocide that devastated the country and claimed more than 10,000 lives per day during the first weeks under the nose of a ill-equipped UN peacekeeping mission deployed in the country, a rapid deployment never came.

The UN failure in Rwanda has been extensively studied. In part, it had to do with Africa losing its strategic value for most of the Western diplomats in the UN; ;ii and with the U.S. - UN military defeat in Mogadishu on October 3, 1993, just two days before the UNSC authorization for a peacekeeping mission in Rwanda (MINUAR). Kofi Annan, then Deputy Secretary-General in charge of peacekeeping operations, carefully relayed Madeleine Albright's messages: the UN had to avoid new images of U.S. financed UN blue helmets 
engaged in costly military defeats in conflicts deprived of any strategic interest, if it were to preserve the (indispensable) support of the U.S. Congress $(30 \%$ of the whole peace operations budget at that time). If the UN could not marshal the material, logistical and doctrinal means to succeed on the field, or at least to avoid a media-covered and humiliating defeat, it would better not to act at all and remain out of sight on the ground. liii This is what the Secretariat obtained from the UN mission in Rwanda, without any reaction in the UNSC during the first weeks of the genocide.

With the U.S. and UN withdrawals from Somalia and the shameful UN inaction in the heart of the Rwandan genocide, worrying messages were sent by the UN to entrepreneurs of violence: If they want to kick out the international forces so to carry on violent projects, they should target directly and in the most visible manner these forces, and particularly Western personnel, as Mohammed Farah Aideed's men did in Somalia in June and October 1993. Indeed, intervening states in these peripheral conflicts rarely shared the kind of high-valued interests that drive their massive and durable military actions in other parts of the world, whatever the human costs are (Vietnam, Chechnya, Afghanistan, Iraq, etc.). In Rwanda, the day after President Habyarimana's assassination on April 6, 1994, the Garde présidentielle rallied Colonel Théoneste Bagosora's plan for the constitution of a new government faithful to the Hutu-Power extremist ideology and killed in the cruelest manner the moderate Prime Minister (Agathe Uwilingiyimana) and ten of the Belgian blue helmets who were protecting her. Because the UN Secretariat opposed any firm Belgian military response to the killers, the latter chose to quit the MINUAR, depriving the UN force of its offensive backbone. liv According to military that were in the field at the time, there was no doubt that a perverse lesson had been carried over from the UN failure in Mogadishu. ${ }^{\text {Iv }}$ 
The American delegation had sought to avoid humiliation and pushed the UN to more carefully select where it should intervene and when it should withdraw. This was applied to Rwanda. As the President had been killed and the fighting had resumed, the UNSC, and in particular the delegation that asked to involve the UNSC in this situation, had to recognize their impotence and quit (as the U.S. did in Somalia in March 1994), despite the diffusion of the genocide, rather than keep on with their mission which would plunge the UN deeper into an inextricable situation. Importantly enough, in the U.S. delegations' eye, such withdraw would also teach signing parties of peace agreements that they could not rely on a UN support and presence unless they were willing to comply with what they had agreed upon. ${ }^{\text {.vi }}$ Obviously, such a "lesson" did not work in a context of genocide.

The UNSC member states, however, particularly the leading one, could harness by themselves the required means for intervening, with chances of success, in order to restore minimal conditions for resuming UN peace activities. ${ }^{\text {lvii }}$ This is precisely what occurred in Sierra Leone after the May 2000 crisis. At this time, around 500 UNAMSIL personnel were abducted by discontented RUF commanders in different parts of Sierra Leone. Whereas the U.S. immediately advocated for a withdrawal, Tony Blair's government chose to come to the rescue of "his" UN mission under siege and to avoid a new fiasco. Indeed, the U.K. delegation progressively had become involved as an active leader of this mission beginning in 1999. ${ }^{\text {lviii }}$ It thus demonstrated to the other UNSC members that an intrusive and robust intervention, first from national forces and then UN peacekeepers under its diplomatic lead, might provide stabilization.

Indeed, conditions were particularly favorable. Means were made available from London, from the Guinean army, then from the U.S. and the international donors. And the challenges to overcome were relatively low: a small territory, and a relatively weak rebel 
group with increasingly exhausted combatants. ${ }^{\text {lix }}$ The Sierra Leone regime had benefited from foreign support, notably the U.K.-led reform of the security sector provided by the British/International Military Assistance Training Team. It simultaneously remained under international scrutiny in order to ensure that the UNSC-supported action would not indirectly favor particularly violent or destabilizing political practices or strategies from President Kabbah and his regime.

In the UN, the U.K. leading role in 2000-2002 was reflected in various indications, such as the intense diplomatic statements from the U.K. delegation concerning Sierra Leone, the key persons appointed to the UNAMSIL leadership (the Nigerian ambassador Oluyemi Adeniji as the chief of the mission and the British Alan Doss as his main deputy and UNDP resident coordinator), or the UNSC public meeting organized by British ambassador Jeremy Greenstock, then chairing the Council, on July 18, 2002, which was dedicated to the Mano River region's crises. ${ }^{1 \mathrm{x}}$

We claim below that this British success in Sierra Leone reflects a normative change concerning how UNSC members have collectively conceived of the leadership role in peacekeeping operations since the early 2000s.

\section{"LEADERSHIP" AND NORMATIVE CHANGE: PROTECTING UN MISSIONS FROM INTERNATIONAL DISCREDIT}

Some of the U.S. preferences in the heart of critical moments in UN operations, such as the Rwandan genocide, or the May 2000 crisis for the UNAMSIL finally inspired operational recommendations in the 2000 Brahimi report on reforming UN peacekeeping operations. ${ }^{\text {xi }}$ But they are rarely presented sociologically as a change occurring first in the informal social rules supporting the position of diplomatic leader to the UNSC. Indeed, the intersubjective understanding of the role of the leader had changed. 
The belated, UN-endorsed French Operation Turquoise (22 June-22 August 1994) reflects, after six weeks of inaction (and the decision to withdraw almost all the MINUAR contingents on April 21), an understanding of this new model of leadership. It inspired much sarcasm and criticism regarding previous French action and inaction. Some challenged the French as an impartial and locally respected protection of civilians.

During the UNSC public meeting on May 16, 1994 (which finished late at night), the Ambassador of New-Zeeland, Colin Keating - who had previously chaired the April 21 UNSC meeting when resolution 912 (that shamefully reduced the MINUAR staff) had been adopted, pronounced unusually severe words against the Rwandan regime. He thus indirectly contested the UNSC choices to which he and his colleagues had previously agreed. ${ }^{\text {lii }}$ In the same evening, the Czech Ambassador, Karel Kovanda, recalled his previous statement (made on May 8) that genocide was going on in Rwanda. He thus openly disregarded the taboo previously promoted by the U.S. delegation against the use of the "g-word."

The debates about a UN mandate for Turquoise engendered many criticisms and suspicions from the delegations of Brazil, China, New-Zealand, Nigeria and Pakistan. ${ }^{\text {liii }}$ The operation only won a UNSC mandate thanks to firm U.S. support. This did not prevent the UNSC members from doubting the French authorities' ability to keep a grip on the local actors, as their previous local partners were out of power and Paul Kagamé, the coming Rwandan president, proved himself the master of security (and insecurity) issues in the region. ${ }^{\text {1xiv }}$

To accurately measure the consequences of the French Rwandan experience in the medium term, one needs to observe the course of the diplomatic interaction within the UNSC during another crisis, partly linked to the 1994 Rwandan genocide: the so called "refugee crisis" in the autumn of 1996 and the rebellion that toppled President Joseph Mobutu Sese 
Seko in May 1997. In August 1996, Mobutu's imploding regime faced an armed uprising in the eastern provinces contiguous to Rwanda. Political tensions were high in South and North Kivu among different populations over land rights and citizen rights. The influx of tens of thousands of Hutu Rwandan refugees after the genocide in Rwanda into camps around Goma and Bukavu exacerbated the situation. These tensions turned into a more organized rebellion when the Rwanda and Uganda supported Alliance des forces démocratiques de liberation (AFDL) attacked the Hutu refugee camps in Zaire (DRC). Rwanda and Uganda sought to overthrow the then sick president Mobutu and to remove the threat of Hutu armed groups (notably composed of former génocidaires and their families) settled next door. ${ }^{1 \mathrm{xv}}$

Zaire in 1996 revealed one fact: the genocide in Rwanda (which will be progressively interpreted as one of the most shameful, costly failures for the $\mathrm{UN}$, in terms of image and credibility) lost the French delegation its previously routine leading position concerning the Great Lakes and Francophone Africa at the UNSC table. It made it easy-to-grasp arguments against the French call for immediate action in Zaire/DRC. Thwarted by this experience, the French military leadership itself categorically opposed any bilateral military intervention, in the Great Lakes region. ${ }^{\text {lxvi }}$

The crisis in Zaire was also an opportunity to weigh the consequences of a reluctant diplomatic leader, in this case the U.S., when no UN operation was already deployed. For domestic and diplomatic reasons, the U.S. diplomats to the UN worked at avoiding any UN military response in the region, and manifestly preferred to lean on local military strongmen (Ugandan Yoweri Museveni and Rwandan Paul Kagamé), then considered as "New African Leaders," to install domestic and regional political order. ${ }^{\text {lxvii }}$

The U.S. delegation also helped to marginalize the French delegation by championing another potential leading delegation concerning the military operation to come, the Human 
Security-advocate, Canada. UNSC members (including the French) supported the project of a Canadian-led multilateral military operation aimed at protecting the refugees and civilians in Eastern Zaire. ${ }^{\text {xviii }}$ This operation (named Assurance) was finally abandoned. ${ }^{\text {lxix }}$ Yet, thousands of Hutu Rwandan refugees who had refused to go back home were killed by the Rwanda army and the AFDL rebels. Rwanda could then take partial control of mineral resources in the region. ${ }^{1 \mathrm{xx}}$

The French military came back to the region in spring 2003, with operation Artémis (limited to the city of Bunia, Ituri); but this time under the auspices of the European Union. A few months before, the French delegation (led by Ambassador Jean-David Levitte) had renewed their collectively-acknowledged leading role to the UNSC on this very dossier. The role was exerted very prudently and in close cooperation with the Americans and the British.

Artémis reflected the European Policy for Security and Defense policy of more aggressively intervening overseas. ${ }^{1 x x i}$ It also affirmed the responsibility of the leading UNSC delegation to gather the political will and the military means for coercive action. In this case, instability and visible large-scale violence against civilians was spreading in Bunia and the region, and the MONUC (the UN Mission in DRC) first appeared incapable of stopping it. The violence occurred immediately after international actors and the UN had negotiated the withdrawal of the Ugandan military forces previously occupying Bunia. This violence thus directly challenged the UN. Undoubtedly, things are complex in the huge territory of the DRC and the regional war that spread in 1998 reflected that complexity. Attempts to meet security concerns both for the regime and for civilians in close relation with the new internationallysupported president, Joseph Kabila, remained fragile. Artémis, nevertheless, offers an arresting point of comparison with the British leading role in Sierra Leone. 
In Sierra Leone, the progressive firm British leadership undoubtedly originated in a particular context in British internal politics, as well as in regard to the UN department for peacekeeping operations (DPKO) relationship with the U.S. administration. The newly appointed UN chief of peacekeeping operations, Jean-Marie Guéhenno, started his mandate with new confidence and ambition after five years of decline in UN peace activities. He would keep this Sierra Leone case in mind during his mandate. Yet, this change primarily embodies in how UNSC members conceived the diplomatic leadership on UN peace operations, and the practical norms attached to this informal position. This normative change concerned the new political costs when UN is visibly militarily humiliated, and the necessary firm involvement of the diplomatic leader to avoid such situations. Naturally, in an interactionist approach, there is no reason for such normative change to remain indefinitely. New political contexts; in the U.S., in the UN, or in African regions in turmoil, may inspire new ways of approaching diplomatic leadership within the UNSC. Nonetheless the collective caution concerning the credibility of the UNSC supported peacekeeping missions have led to a normative change strengthening the leadership role.

\section{CONCLUSION}

Intense media coverage at the apex of an international crisis and outbreak of large scale violence should not restrict the assessment of international action to only the "crisis" moment. The everyday political practices that led-up to the crisis need as much attention.

A focus on the more regular practices from international peacekeeping and security managers is all the more relevant when international actors have already liaised with local political and military forces, or when targeted states have existing international interventions and programs. Crises and outbreaks of violence do often occur in the middle of peacekeeping routines, reconstruction programs, or third-party mediation processes. The impact of these 
interventions, nonetheless, must be assessed from the perspective of both the local actors in war-torn areas and to political-military leaders elsewhere. And, of course, the impact of the interventions must also encompass what domestic constituencies in the intervening state think about them and how intra-organizational politics shape, or are being shaped, by these interventions.

Multilateral conflict management propels different logics of collective acknowledgement and legitimization among peers within the UNSC. The leading role assumed by a specific UNSC delegation on a specific dossier embodies some of these logics. It reflects that fact that multilateral interactions are not necessarily separated from the prior bilateral relations between external interveners and local political and military forces. Indeed, multilateral operations can often provide resources as to extend a bilateral engagement between a UNSC member and a partner state in turmoil. The French lead on Rwanda in 19931994 facilitated UN peacekeeping operations, which compensated for the erosion of previously mobilized bilaterally resources. But new resources can also transform the current conflict situation in an unexpected way. It may expose current positions of influence within the UNSC to rapid transformations at the expense of the holders of these positions. Indeed, the French delegation lost its leading position on Great Lakes. The UNSC decision-making about Rwanda and its follow-up in Zaire/ DRC, as well as the progressively firm leadership assumed by the United Kingdom on the Sierra Leon dossier from 2000, reveal some lessons that have been learned since the end of the 1990s by delegations keen to remain in tune with their colleagues in the UNSC, and particularly with the U.S. Congress.

One of the important lessons we learn from the interactionist approach is the importance of protecting international peacekeeping operations from being discredited in the eyes of local actors, who are tempted to renege on what they previously promised. As well, 
domestic constituencies of the main backers of peacekeeping operations need to be reassured. In the $2000 \mathrm{~s}$, the protection of the credibility of peacekeeping operations required that the diplomatic leaders, when clearly identified in the UNSC, commit important material and political means to avoid highly visible military humiliation and political drawbacks. In these critical situations, more than ever, UN peacekeeping operations leaned on the diplomatic actors who had supported and led the broader multilateral responses to Africa's multifaceted crises. This obviously applied to the most recent French involvement in Côte d'Ivoire. This is not to say that every single UN military response in the 2000s has necessarily been efficient. Think of MONUC in DRC or UNAMID in Darfur. But when a diplomatic leadership was clearly assumed for a UN mission in the UNSC, it consisted at least in avoiding any military humiliation on the ground with large scale media coverage.

Finally, from a methodological point of view, what we call "lessons" did not stem from well defined strategic plans but from practical adjustments entrenched in the day-to-day interaction among the UNSC delegations, particularly among the permanent members' diplomats. Disclosing such practical adjustments requires the observation of precise arenas of interaction, followed by an inductive reasoning of what was observed. Deduction of political effects and outcomes from overall power positions on a global scale, alone, will offer on an incomplete position of how peacekeeping works.

i See Thomas J. Bassett, and Scott Straus, "Defending Democracy in Côte d'Ivoire. Africa Takes a Stand", Foreign Affairs 90, no. 4 (2011): 130-140.

ii Daniel Bach, “France's Involvement in Sub-Saharan Africa: A Necessary Condition to Middle Power Status in the International System", in Africa and Europe: From Partition to Interdependence or Dependence, ed. Amadu Sesay (London: Crom Helm, 1986), 75-85; Maja Bovcon, "France’s Conflict Resolution Strategy in Côte d'Ivoire and its Ethical Implications", African Studies Quarterly 11, no. 1 (2009): 1-24; Pierre Lellouche, and Dominique Moisi, "French Policy in Africa: A Lonely Battle against Destabilization", International Security 3, no. 4 (1979): 108-133; "René Otayek, La Libye face à la France au Tchad: Qui perd gagne ?”, Politique 
Africaine 16 (1984): 66-85; David Yost, "French Policy in Chad and the Libyan Challenge", Orbis 26, no. 4 (1983): 965-998.

iii In this quest for an in-depth insight on the UNSC, one cannot omit the seminal, anthropological work fashioned by Michael Barnett's on the UNSC everyday work during the genocide in Rwanda. Michael N. Barnett, "UN Security Council, Indifference, and Genocide in Rwanda", Cultural Anthropology 12, no. 4 (1997): 551-578; and Eyewitness to a Genocide: the United Nations and Rwanda (Ithaca: Cornell University Press, 2002).

iv With more than 120.000 personnel working for the UN missions on the field (almost 100.000 in uniform), and close to 8 billion US dollars.

v Adekeye Adebajo, The Curse of Berlin. Africa after the Cold War (London: Hurts \& Co., 2010), 59.

vi Eric Berman, and Katie Sams, Peacekeeping in Africa: Capabilities and Culpabilities (Geneva: United Nations Institute for Disarmament Research, 2000); Ian Taylor, and Paul Williams (eds.), Africa in International Politics: External Involvement on the Continent (London: Routledge, 2004); Mats Berdal, and Spyros Economides (eds.), United Nations Interventionism, 1991-2004 (Cambridge: Cambridge University Press, 2007). vii Thorsten Benner, Stephan Mergenthaler, and Philipp Rotmann, The New World of UN Peace Operations (Oxford: Oxford University Press, 2011); Paul Diehl, and Daniel Druckman, Evaluating Peace Operations (London: Lynne Rienner, 2010); Lise Morjé Howard, UN Peacekeeping in Civil Wars (Cambridge: Cambridge University Press, 2008).

viii Séverine Autesserre, The Trouble with the Congo: Local Violence and the Failure of International Peacebuilding (Cambridge: Cambridge University Press, 2010); Giulia Piccolinon and John Karlsrud, "Withering Consent, but Mutual Dependency: UN Peace Operations and African Assertiveness", Conflict, Security and Development 11, no. 4 (2011): 447-471; Stephen J. Stedman, "Spoilers Problems in Peace Operations", International Security 22, no. 2 (1997): 5-53; Denis M. Tull, and Andreas Mehler, "The Hidden Costs of Power Sharing: Reproducing Insurgent Violence in Africa", African Affairs 104, no. 416 (2005): 375398; William Zartman, Ripe for Resolution: Conflict and Intervention in Africa (New York: Oxford University Press, 1985).

ix Mary Douglas, How Institutions Think (Syracuse: Syracuse University Press, 1986); Lena Jayyusi, Categorization and the Moral Order (Boston: Routledge \& K. Paul, 1984).

x Nicholas G. Onuf, "Constructivism: a User's Manual", in International Relations in a Constructed World (eds.), Vendulka Kubalkova, Nicholas G. Onuf, and Paul Kowert (Armonk: Sharpe, 1998), 58-78; James March, and Johan Olsen, "Institutional Dynamics of International Political Orders", International Organization 52, no. 4 (1998): 943-969; Alexander Wendt, Social Theory of International Politics (Cambridge: Cambridge University Press, 1999).

xi Nicholas G. Onuf, World of Our Making: Rules and Rule in Social Theory and International Relations (Columbia, University of South Carolina Press, 1989); Friedrich Kratochwil, Rules, Norms, and Decisions: On the Conditions of Practical and Legal Reasoning in International Relations and Domestic Affairs (Cambridge: 
Cambridge University Press, 1989); Keith Krause, "Critical Theory and Security Studies: The Research Programme of 'Critical Security Studies'”, Cooperation and Conflict 33, no. 3 (1998): 298-333.

xii Martha Finnemore, "Constructing Norms of Humanitarian Intervention", in The Culture of National Security, ed. Peter Katzenstein (New York: Columbia University Press, 1996), 153-85; Neta Crawford, Argument and Change in World Politics: Ethics, Decolonization, and Humanitarian Intervention (Cambridge: Cambridge University Press, 2002); Ian Hurd, "Legitimacy and Authority", International Organization 53, no. 2 (1999): 379-408.

xiii Peter V. Jakobsen, "The Transformation of United Nations Peace Operations in the 1990s. Adding Globalization to the Conventional 'End of the Cold War Explanation' ", Cooperation and Conflict 37, no. 3 (2002): 267-282; Roland Paris, At War's End: Building Peace after Civil Conflict (Cambridge: Cambridge University Press, 2004); Oliver P. Richmond, "The Globalization of Responses to Conflict and the Peacebuilding Consensus", Cooperation and Conflict 39, no. 2 (2004): 129-150.

xiv Mark Duffield, Development, Security and Unending War: Governing the World of Peoples (Cambridge: Polity, 2007).

xv David Chandler, Empire in Denial: the Politics of State-Building (London: Pluto, 2006).

xvi Martha Finnemore, "Constructing Norms of Humanitarian Intervention”; Neta Crawford, Argument and Change in World Politics.

xvii Alexander Wendt, Social Theory of International Politics (Cambridge: Cambridge University Press, 1999), notably the chapter 5 "The State and the Problem of Corporate Agency".

xviii On these processes of "reflective appraisals", "mirroring", "role-taking" and "altercasting", see Alexander Wendt, Social Theory of International Politics, chapter 7 "Process and Structural Change", 326-335 notably.

xix Brent J. Steele, Ontological Security in International Relations (London, New York: Routledge, 2007).

xx Peter Berger, and Thomas Luckmann, The Social Construction of Reality: A Treatise in the Sociology of Knowledge (New York: Penguin Press, 1971); Pierre Bourdieu, The Logic of Practice (Stanford: Stanford University Press, 1990); Anthony Giddens, The Constitution of Society: Outline of the Theory of Structuration (Cambridge: Polity, 1984); Erving Goffman, Frame Analysis. An Essay of the Organization of Experience (New York: Harper and Row, 1974).

xxi In his constructivist study on the changing Chinese policy toward arms control after China rallying the UN Conference on Disarmament, A. Iain Johnston exemplified how important it was to distinguish the different groups of state agents involved and their precise roles in multilateral and internal interactions. Alastair I. Johnston, Social States: China in International Institutions, 1980-2000 (Princeton: Princeton University Press, 2008).

xxii According to Anthony Giddens, social contexts and social structures exist as long as they impregnate day-to-day practices and are enacted and reproduced through them, in a more or less distant or informal way. Anthony Giddens, The Constitution of Society. 
xxiii Theodore R. Schatzki, Karin Knorr Cetina, and Eike von Savigny, The Practice Turn in Contemporary Theory (New York: Routledge, 2001).

xxiv Iver B. Neumann, "Returning Practice to the Linguistic Turn: The Case of Diplomacy”, Millennium 31, no. 3 (2002): 627-651; Iver B. Neumann, “ 'A Speech That the Entire Ministry May Stand for', or: Why Diplomats Never Produce Anything New”, International Political Sociology 1, no. 2 (2007): 183-200; Vincent Pouliot, International Security in Practice: the Politics of NATO-Russia Diplomacy (Cambridge: Cambridge University Press, 2010); Wanda Vrasti, "The Strange Case of Ethnography and International Relations", Millennium 37; no. 2 (2008): 279-301.

xxv Pierre Bourdieu, The Logic of Practice, notably 40-41, 62, 66-67, 80, 108-111; Anthony Giddens, Constitution of Society, 84-87; Peter Berger and Thomas Luckmann, Social Construction of Reality, 43-48. One may also usefully refer to the classic Howard S. Becker, Outsiders: Studies in the Sociology of Deviance (New York: the Free Press, 1991).

xxvi For two accounts with different theoretical implications, see Giddens' account on "practical consciousness" (as opposed to the "discursive consciousness") and Bourdieu's "logic of practice" founded on the concept of "habitus". Anthony Giddens, Constitution of Society, notably 3-7, 46-9, 281; Pierre Bourdieu, The Logic of Practice, notably 26-27, 48-54, 91-2, 103-104, 297-298. See also Berger and Luckmann, Social Construction of Reality, 37-38.

xxvii Into the French delegation, some even say "on a le lead" (using the English word).

xxviii Howard Adelman, and Astri Suhrke (eds.), The Path to Genocide: Uganda to Zaire (New Brunswick, Transaction Press, 1999), 37; Michael N. Barnett, "UN Security Council, Indifference, and Genocide in Rwanda”, 572; Andrew Cooper and Ian Taylor, “ 'Made in Africa' versus 'Out of Africa': Comparing South Africa's Non-Leadership with Canada's Leadership in the 1996 Crisis in Eastern Zaire”, The Journal of Commonwealth and Comparative Politics 39, no. 1 (2001): 23-41; Bruce Jones, “"Intervention without Borders': Humanitarian Intervention in Rwanda, 1990-94”, Millennium 24, no. 2 (1995): 225-249; Umberto Tavolato, “Breaking Colonial Borders: The African Union's Role in the Southern Sudan's Secession” [in French], Politique Africaine 122 (2011): 101-119.

xxix Lise Morjé Howard, UN Peacekeeping in Civil Wars, 11-13; Teresa Whitfield, Friends Indeed? The United Nations, Groups of Friends, and the Resolution of Conflict (Washington: United States Institute of Peace, 2007), 6 .

xxx Fen O. Hampson, and Michael Hart, Multilateral Negotiations: Lessons from Arms Control, Trade, and the Environment (Baltimore: Johns Hopkins University Press, 1995), 42.

xxxi Richard A. Higgott, and Andrew F. Cooper, "Middle Power Leadership and Coalition Building: Australia, the Cairns Group and the Uruguay Round of Negotiations”, International Organization 44, no. 4 (1990): 589-632; Stéphanie Novak, "Decision Rules, Social Norms and the Expression of Disagreement: the Case of Qualified-Majority Voting in the Council of the European Union”, Social Science Information 49, no. 1 (2010): 93. 
xxxii Margaret G. Hermann (eds.), Leaders, Groups and Coalitions: Understanding the People and Processes in Foreign Policymaking (Oxford: Blackwell, 2001).

xxxiii Joseph S. Nye, Bound to Lead: the Changing Nature of American Power (New York: Basic Books, 1990).

xxiv $\quad$ Robert Gilpin, War and change in world politics (Cambridge: Cambridge university press, 1983).

xxxv About this U.S. frequent strategy, see Whitfield, Friends indeed?, 62.

xxxvi Adelman and Suhrke, The Path to Genocide, 37; Bruce Jones, Peacemaking in Rwanda: The Dynamics of Failure (Boulder: Lynne Rienner, 2001).

xxxvii Christopher Clapham, Africa and the International System: The Politics of State Survival (Cambridge: Cambridge University Press, 1996), chapter 4; Alison Brysk, Craig Parsons, and Wayne Sandholtz, "After Empire: National Identity and Post-Colonial Families of Nations", European Journal of International Relations 8, no.2 (2002): 267-305 ; Louis Balmond (ed.), Les interventions militaires françaises en Afrique (Paris: A. Pedone, 1998); Daniel Bourmaud, "La politique africaine de Jacques Chirac : les anciens contre les modernes", Modern and Contemporary France 4 (1996): 431-442; Jean-Paul Ngoupandé, L'Afrique sans la France. Histoire d'un divorce consommé (Paris: Albin Michel, 2002).

xxxviii France, Assemblée nationale, Pierre Brana and Bernard Cazeneuve, Enquête sur la tragédie rwandaise, Rapport d'information déposé par la Mission d'information de la Commission de la Défense nationale et des forces armées et de la Commission des Affaires étrangères sur les opérations militaires menées par la France, d'autres pays et l'ONU au Rwanda entre 1990 et 1994, Paris, n 1271, December 1998; Olivier Lanotte, La France au Rwanda (1990-1994) : entre abstention impossible et engagement ambivalent (Bruxelles: P.I.E. Peter Lang, 2007); OAU (Organisation of African Unity), Rwanda: The Preventable Genocide: The Report of the International Panel of Eminent Personalities to Investigate the 1994 Genocide in Rwanda and the Surrounding Events (Addis Ababa, Ethiopia: Organisation of African Unity, 2000); Gérard Prunier, The Rwanda Crisis: History of a Genocide (London: Hurst, 1997).

xxxix France, Enquête sur la tragédie rwandaise, vol. 1, 299.

xl Comfort Ero, "UN Peacekeeping in West Africa: Liberia, Sierra Leone and Côte d'Ivoire", in From Global Apartheid to Global Village: Africa and the United Nations, ed. Adekeye Adebajo (Scottsville: University of Kwazulu-Natal Press, 2009); Jean-Marc Châtaigner, L'ONU dans la crise en Sierra Leone. Les méandres d'une négociation (Paris: CEAN/Karthala, 2005).

xli Adekeye Adebajo, Building Peace in West Africa: Liberia, Sierra Leone and Guinea Bissau (Boulder: Lynne Rienner, 2002); Funmi Olonisakin, Peacekeeping in Sierra Leone: The Story of UNAMSIL (Boulder: Lynne Rienner, 2008); David Keen, “Sierra Leone's War in a Regional Context: Lessons from Interventions”, in Human Security Doctrine for Europe, eds. Marlies Glasius, and Mary Kaldor (London: Routledge, 2005); Paul Richards, Fighting for the Rain Forest: War, Youth \& Resources in Sierra Leone (Portsmouth: Heinemann, 1996).

xlii Tull and Mehler, "The Hidden Costs of Power Sharing"; Piccolino and Karlsrud, "Withering Consent, but Mutual Dependency". 

and Sierra Leone", International Peacekeeping 11, no. 1 (2004): 103-123; Peter Uvin, Aiding Violence: the Development Enterprise in Rwanda (West Hartford: Kumarian Press, 1998).

xlv Clapham, Africa and the International System; Marine Lefèvre, Le soutien américain à la francophonie. Enjeux africains, 1960-1970 (Paris: Presses de Sciences Po, 2010).

xlvi Adekeye Adebajo relates the weight of this financial concern from the U.S. during Boutros BoutrosGhali mandate (the appointment of the American Joseph Connor as Undersecretary-General for Management in 1994 was no accident in this regard) then Kofi Annan's one (and the priority given by the Ghanaian to collect a U.S. accumulated debt to the UN of \$1.6 billion). Adekeye Adebajo, The Curse of Berlin, 85-86, 92.

xlvii Alison Des Forges, Human Rights Watch and Fédération internationale des droits de l'homme, "Leave None to Tell the Story": Genocide in Rwanda (New York: Human Rights Watch, 1999); Jean-Paul Kimonyo, Rwanda, un génocide populaire (Paris: Karthala, 2008); Michael Mann, The Dark Side of Democracy: Explaining Ethnic Cleansing (Cambridge: Cambridge University Press, 2005), 428-473; Prunier, The Rwanda Crisis.

xlviii Gilbert Khadiagala, "Implementing the Arusha Peace Agreement on Rwanda", in Ending Civil Wars: The Implementation of Peace Agreements, eds. Stephen J. Stedman, Donald Rothchild, and Elizabeth M. Cousens (Boulder, Lynne Rienner, 2002), 87-106.

xlix Paul Williams, "Peace Operations and the International Financial Institutions".

$1 \quad$ Olonisakin F., Peacekeeping in Sierra Leone, 19.

li Richards, Fighting for the Rain Forest, 85.

lii Peter J. Schraeder, "Removing the Shackles? U.S. Foreign Policy Toward Africa After the End of the Cold War", in Africa in the New International Order: Rethinking State Sovereignty and Regional Security, eds. Ed Keller, and Don Rothschild (Boulder: Lynne Rienner, 1996), 187-203.

liii Roméo Dallaire, and Brent Beardsley, Shake Hands with the Devil: the Failure of Humanity in Rwanda (Toronto: Random House Canada, 2003); Samantha Power, "A Problem from Hell": America and the Age of Genocide (New York: Basic Books, 2002), 329-390; OAU, Rwanda: The Preventable Genocide; United Nations, Report of the Independent Inquiry into the Actions of the United Nations during the 1994 Genocide in Rwanda (New York: United Nations, 1999); Linda Melvern, A People Betrayed: the Role of the West in Rwanda's Genocide (London: Zed Books, 2009). Adekeye Adebajo offers interesting elements about this tragic episode for the UN Secretariat, through Boutros Boutros-Ghali and Kofi Annan's personal experience of it. Adekeye Adebajo, The Curse of Berlin, chapter 4 "The Pharaoh and the Prophet: Boutros Boutros-Ghali and Kofi Annan".

liv Dallaire and Beardsley, Shake Hands with the Devil.

Iv Paolo Tripodi, "When Peacekeepers Fail Thousands are Going to Die. The ETO in Rwanda: a Story of Deception”, Small Wars \& Insurgencies 17, no. 2 (2006): 221-236. 

among UN Diplomats", Global Society 24, no. 2 (2010): 151-171.

lviii Châtaigner, L'ONU dans la crise en Sierra Leone, 112-113; Comfort Ero, "British Foreign Policy and the Conflict in Sierra Leone", in Sierra Leone, One Year after Lomé: One-Day Analytical Conference on the Peace Process in London, 15 September 2000, ed. O. Oludipe (London: Centre for Democracy and Development Planning Series, no. 5, 2000), 110-111; Paul Williams, "La Grande-Bretagne de Tony Blair et l'Afrique", Politique africaine, 94 (2004): 116.

lix Olonisakin, Peacekeeping in Sierra Leone; Paul Richards, and James Vincent, "Sierra Leone: Marginalization of the RUF", in From Soldiers to Politicians. Transforming Rebel Movements after Civil War, ed. Jeroen de Zeeuw (Boulder: Lynne Rienner, 2008), 81-102.

lx United Nations official records S/PV.4577 Resumption 1.

Ixi United Nations, Report of the Panel on United Nations Peacekeeping Operations (New York: United Nations, 17 July 2000).

1xii United Nations official records S/PV.3377.

Ixii $\quad$ United Nations official records S/PV.3392.

Ixiv African Rights, Rwanda: Death, Despair, and Defiance (London: African Rights, 1995), 698-711; France, Enquête sur la tragédie rwandaise, vol. 1, 288-289; Jones, "Intervention without Borders", 231.

Ixv HRW (Human Rights Watch) / FIDH (Fédération internationale des droits de l'homme), Democratic Republic in the Congo: What Kabila is Hinding. Civilian Killings and Impunity in Congo. Report, October 1997. www.hrw.org/reports97/congo (January 1, 2005). See also René Lemarchand, "Foreign Policy Making in the Great Lakes Region", in African Foreign Policies: Power \& process, eds. Gilbert M. Khadiagala, and Terence Lyons (Boulder: Lynne Rienner, 2001), 87-106; Johan Pottier, Re-Imagining Rwanda: Conflict, Survival and Disinformation in the Late 20th Century (Cambridge: Cambridge University Press, 2002); Gérard Prunier, From Genocide to Continental War: the 'Congolese' Conflict and the Crisis of Contemporary Africa (London, Hurst \& Co., 2009); and Peter Schraeder, "Belgium, France, and the United States", in Security Dynamics in Africa's Great Lakes Region, Boulder, ed. Gilbert M. Khadiagala (London: Lynne Rienner, 2006), for different accounts. Ixvi Interviews with concerned actors and the study of French diplomatic cables dated by November 14, 1996, support this claim. Some actors told us that the French had to complain as their delegation was not even invited in operational meetings preparing the military intervention (that never came). The article "As Mobutu Totters, France Ponders Options", New York Times, April 15, 1997, gives some ex post indications about this French diplomatic defeat.

1xvii Peter Rosenblum, "Irrational Exuberance: The Clinton Administration in Africa", Current History 100, no. 655 (2002): 195-203.

Ixviii Resolution \#1080 authorizing the operation was adopted on November 15, 1996. In this public meeting, the UNSC welcomed at its table 19 delegations other than the UNSC members, and the draft for the resolution was eventually sponsored by 33 delegations at end of the session, and adopted unanimously by the UNSC. United Nations official records S/PV.3713. See John B. Hay, Conditions of Influence: a Canadian Case 
Study in the Diplomacy of Intervention, Occasional paper n 19 (Ottawa: Carleton University, The Norman Paterson School of International Affairs, 1999).

lxix The return of numbers of refugees in Rwanda after their camps having been dismantled by the Rwandan Patriotic Army in November in front of international media cameras, and the incessant technical hesitations and demands from the U.S. delegation towards the Canadian planners of the operation, demobilised the diplomatic supports of the operation. Ibid.

Ixx HRW / FIDH, Democratic Republic in the Congo; Lemarchand, "Foreign Policy Making in the Great Lakes Region"; Pottier, Re-Imagining Rwanda.

Ixxi Niagalé Bagayoko and Marie V. Gibert, "The Linkage between security, Governance and Development: the European Union in Africa", Journal of Development Studies 45, no. 5 (2009): 789-814. 